\title{
Presenteeism Among Older Workers $(\geq 45$ years) with Coronary Heart Disease: An Integrative Literature Review
}

\author{
Victoria Vaughan Dickson*
}

New York University College of Nursing, 726 Broadway,10 ${ }^{\text {th }}$ Floor, New York, NY 10003, USA

\begin{abstract}
As the American workforce ages, health problems associated with the aging process, like coronary heart disease (CHD) raise new occupational health issues. To date, research on employment among patients with CHD has focused on return to work after an adverse event (e.g., heart attack) as an outcome with little attention paid to how workers function once back at work. The purpose of this integrative literature review was to examine presenteesim among older workers with CHD. The electronic databases that were utilized for this review include: Pubmed, CINAHL, Medline, and PsycInfo with limitations set as published in English from 1992 to 2012 and adults over age 45 (to capture studies focused on older workers). Twelve studies in which presenteeism was measured in older workers with CHD were reviewed. There were 3 key findings: 1) definitions and measurement of presenteeism and CHD diagnosis were inconsistent, 2) the primary focus was on quantifying the economic impact of presenteeism, and 3) job-level and individual-level factors that potentially influence presenteeism were not addressed. Implications for future research include the need for methods that address the gaps identified in this review. Recommendations include the need for longitudinal studies that specifically focus on older workers with CHD and development and testing of theoretical frameworks to guide research design.
\end{abstract}

Keywords: Presenteeism, Work Limitations, Productivity, Older Workers, Heart Disease.

\section{INTRODUCTION}

According to the Bureau of Labor Statistics [1], the American workforce is aging. As a result, health problems associated with the aging process, like coronary heart disease (CHD) present new health and safety challenges. Over 3.5 million workers have CHD with significant work limitations and increased disability [2]. Further, the prevalence of risk factors for CHD is very high in this population. For example, thirty-one percent of the workforce have hyperlipidemia and $15 \%$ have hypertension [3]. Advances in medical care have led to improved trends in morbidity and mortality [4] allowing many workers with CHD to continue working. However, older workers with CHD are 3-times more likely to report work limitations than those without CHD [3]. To date, research on employment among patients with CHD has focused on return to work after an adverse event (e.g., heart attack) as an outcome with little attention paid to how workers function once back at work.

Observational studies have reported that workers with CHD experience increased rates of absenteeism and periods of disability than workers without CHD $[5,6]$. Workers with CHD also can have significant work limitations due to decreased physical capacity or noxious symptoms. These work limitations may be permanent and result in work accommodation (e.g., heavy lifting restrictions). Or, episodic symptoms, such as periods of fatigue, may affect daily work

*Address correspondence to this author at the New York University College of Nursing, 726 Broadway, 10th Floor, New York, NY 10003, USA;

Tel: 212-992-9426; Fax: 212-995-4564, E-mail: vdickson@nyu.edu ability. Sleep disorders and depression, which are also very common among individuals with CHD, have been strongly correlated to decreased productivity while at work in other populations $[7,8]$.

Presenteeism, defined by occupational health scholars as decreased job performance as a result of a health problem [9] is greater in workers with chronic illnesses. [10]. Presenteeism has also been linked to episodic, minor ailments [11], issues related to work life balance [12], job insecurity [13], and feeling stressed $[14,15]$. As a result of being "present" but not fully engaged in work, there is a measurable loss of productivity that is attributed to the worker's physical, mental or emotional state [11].

The causes of presenteeism have been categorized as organizational and job-related. Organizational policies about sick leave as well as incentives for good attendance can foster presenteeism $[12,16]$. Job insecurity is also frequently cited as a reason for presenteeism. Job-related factors including job demands, [15] ease of replacement and decision latitude (i.e., less control over work) have been associated with presenteeism [17]. Having a heavy workload and lack of assistance also contribute to presenteesim [18]. It may be that workers in high demand jobs attend work despite feeling ill in order to maintain a high performance or are disinclined to be absent from work when they know work will not be completed in their absence. Interestingly, a culture of presenteeism has been blamed for promoting presenteesim [13]. For example, work team dynamics that instill an obligation to a work group may result in a worker's reluctance to be absent. In addition to organizational correlates, individual 
worker attitudes including "work ethic" are potent influences on the decision to attend work despite illness [19].

For employers, presenteeism is costly, exceeding $\$ 180$ billion annually [19]. In fact, economists have estimated that presenteeism may account for $84 \%$ of lost productivity costs associated with a health problem; while only $16 \%$ of lost productivity is attributed to absenteeism [20]. For individual workers, presenteeism can take a toll on one's health and well-being. Attending work while ill may result in increased stress and fatigue that can worsen a chronic condition or slow recovery from an episodic illness. Further, functioning at a sub-par level may alienate coworkers, thereby, increasing worker stress [14].

Although presenteeism has received increased attention in occupational health research and notably in chronic conditions [10]; less is known about presenteeism in older workers who stereotypically display greater levels of organizational commitment [21]. One hypothesis is that older workers may be more likely to come to work even when not feeling well out of loyalty or perhaps job insecurity. There is disturbing evidence that workers with CHD, who are more likely to be older, delay in seeking treatment when experiencing chest pain symptoms at work [22] and postpone healthcare appointments due to work commitments. For the older worker with CHD, increased symptoms or associated comorbid conditions like depression or sleep apnea may also increase their vulnerability to presenteeism. Yet there is a dearth of literature investigating presenteeism among older workers with CHD. Therefore, the purpose of this paper is to examine presenteesim among older workers with CHD. Specifically, this paper will explore the literature in which presenteeism has been measured in older workers with CHD and discuss im- plications for future research based upon the gaps in the current literature

\section{METHODS}

This systematic review was guided by the Preferred Reporting Items of Systematic reviews and Meta-Analyses (PRISMA) framework [23]. Briefly, PRISMA provides guidance in the development and reporting of systematic literature reviews through use of systematic and explicit methods to identify, select and critically appraise the relevant literature. The electronic databases that were utilized for this review include: Pubmed, CINAHL, Medline, and PsycInfo with limitations set as published in English from 1992 to 2012 and adults over age 45. The age limit of over age 45 was established to capture studies that focused on older working populations. The twenty-year time period was chosen because of the changing nature of occupational health research and the relatively new conceptualization of presenteeism [24]. Key words included: "presenteeism", "productivity loss", "lost productivity", "work limitations", and "heart", "cardiovascular disease" or "metabolic" in order to capture research on cardiometabolic disorders. Exclusion criteria for this review included: commentaries or editorials, and unpublished dissertations. Studies that examined productivity loss only as a calculation of absenteeism or disability from work, and not presenteeism were excluded. Studies that did not provide results or discuss findings related to heart disease were also excluded. Initially, a total of 50 studies were retrieved and screened for eligibility. Twenty-nine fulltext studies were evaluated. During the data evaluation stage, 12 primary studies including 4 international studies, were retained based on the inclusion and exclusion criteria (Fig. 1). A summary of the results can be found in Table 1.
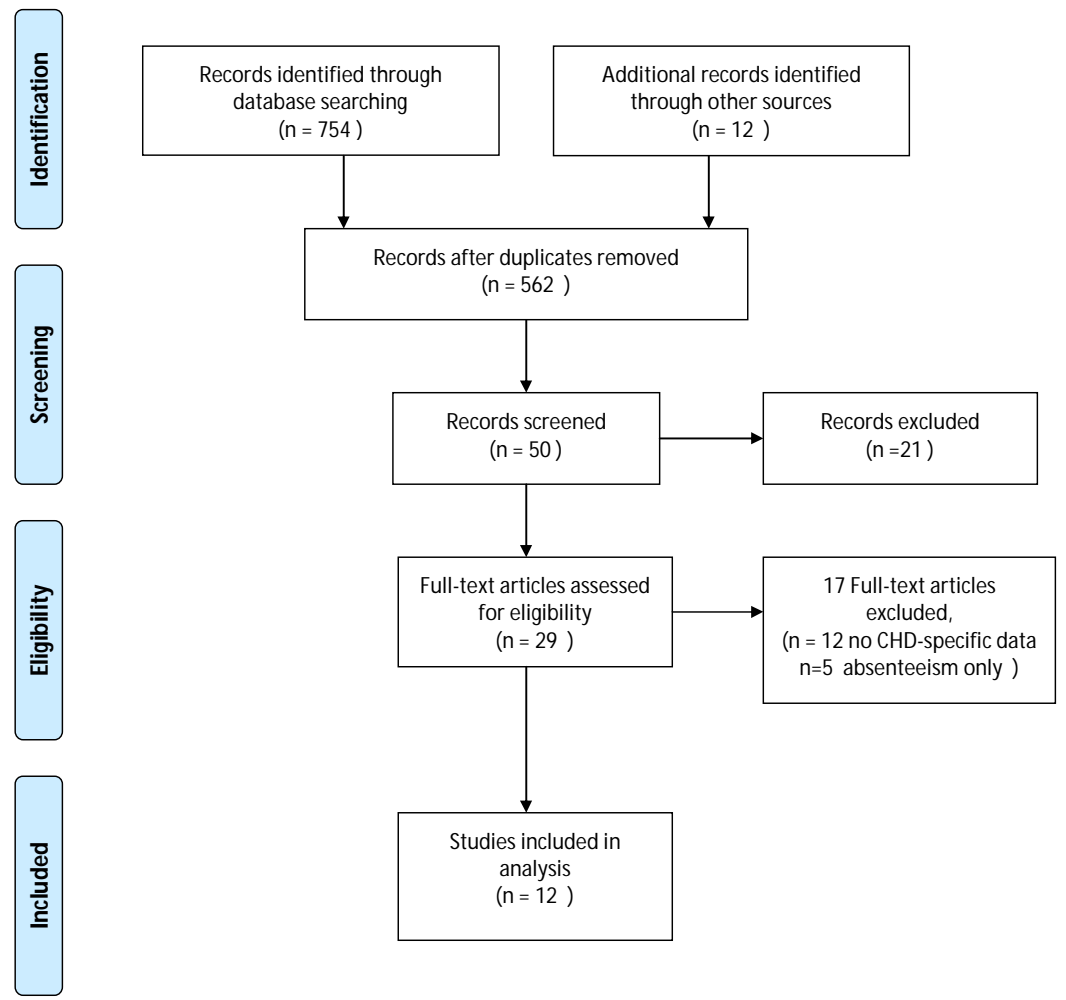

Fig. (1). PRISMA Flow Diagram. 
Table 1. Summary of Results

\begin{tabular}{|c|c|c|c|c|c|}
\hline Study & $\begin{array}{l}\text { Relevant study Pur- } \\
\text { pose Study Design }\end{array}$ & Design & $\begin{array}{l}\text { Total Sample\% } \\
\text { CHD diagnosis }\end{array}$ & Related Key Findings & $\begin{array}{l}\text { Strengths and Limita- } \\
\text { tions }\end{array}$ \\
\hline $\begin{array}{l}\text { Rohr- } \\
\text { backer, } \\
\text { et al. [26] }\end{array}$ & $\begin{array}{l}\text { To establish the burden } \\
\text { of atrial fibrillation (AF) } \\
\text { and other cardiac ar- } \\
\text { rhythmias (CA) in an } \\
\text { employed population }\end{array}$ & $\begin{array}{l}\text { Cohort study } \\
\text { Two cohorts } \\
\text { 1) Cardiac Arrhyth- } \\
\text { mia (CA) vs. non- } \\
\text { CA } \\
\text { 2) Atrial Fibrillation } \\
\text { (AF) vs. non-AF } \\
\text { Secondary analysis of } \\
\text { multi-employer data- } \\
\text { base (all } 50 \text { states) }\end{array}$ & $\begin{array}{l}\text { Total Sample } \\
\text { N=648,150 } \\
\text { Women 27-41\% } \\
\text { Mean age } 41 \\
\text { White } 42-51 \% \\
\text { (race unknown 30- } \\
35 \% \text { ) } \\
\text { Cohort 1:CA } \\
\text { (n=4497) } \\
\text { Women 39\% } \\
\text { Mean age } 45 \text { yrs } \\
\text { Cohort 2: AF } \\
\text { (n=1403) } \\
\text { women } 27 \% \\
\text { mean age } 49 \text { yrs }\end{array}$ & $\begin{array}{l}\text { - } \begin{array}{l}\text { AF \& CA cohorts were } \\
\text { older \& had more comor- } \\
\text { bid conditions }\end{array} \\
\text { Lower productivity (pre- } \\
\text { senteeism) in AF ( } \mathrm{p}=.05 \text { ) } \\
\text { \& CA ( } \mathrm{p}=.01) \text { cohorts } \\
\text { Presenteeism in AF \& CA } \\
\text { may be linked to symp- } \\
\text { toms that affect hourly } \\
\text { productivity but not dis- } \\
\text { ability or absenteeism. }\end{array}$ & $\begin{array}{l}\text { Strengths: Objectively } \\
\text { measured productivity } \\
\text { using electronic meas- } \\
\text { urement (units \& hours } \\
\text { worked) } \\
\text { Cardiac diagnoses de- } \\
\text { rived from healthcare } \\
\text { claims. } \\
\text { Limitations: Presentee- } \\
\text { ism only measured in a } \\
\text { subset of individuals } \\
\text { (task oriented workers) } \\
\text { Diagnosis of AF vs. CA } \\
\text { may include overlap due } \\
\text { to coding of claims. }\end{array}$ \\
\hline $\begin{array}{l}\text { Fonseca, } \\
\text { et al. * } \\
{[31]}\end{array}$ & $\begin{array}{l}\text { To document the rela- } \\
\text { tionship between physi- } \\
\text { cal activity, absentee- } \\
\text { ism, presenteeism \& } \\
\text { healthcare utilization } \\
\text { among Brazilian em- } \\
\text { ployees. }\end{array}$ & $\begin{array}{l}\text { Cross-sectional study of } \\
\text { single employer and } \\
\text { work sector (Automo- } \\
\text { tive Industry workers in } \\
\text { Brazil) }\end{array}$ & $\begin{array}{l}\text { Total Sample } \\
\mathrm{N}=620 \\
\text { Mean age } 38.5 \\
\text { White } 79 \% \\
15.5 \% \text { with heart } \\
\text { disease } \\
\text { (including heart } \\
\text { failure, myocardial } \\
\text { infarction, angina, } \\
\text { stroke, high blood } \\
\text { pressure ) }\end{array}$ & 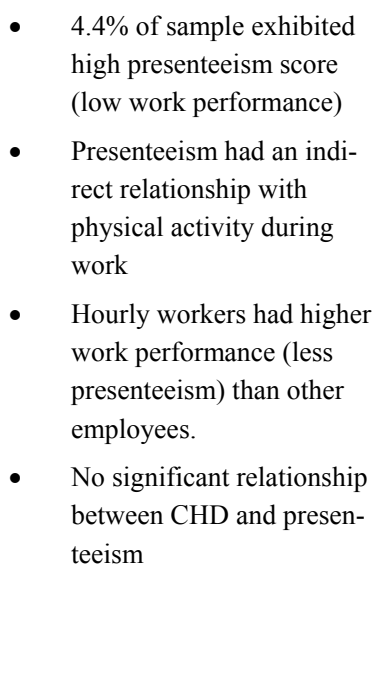 & $\begin{array}{l}\text { Strengths: Covariates } \\
\text { (age, gender, work shift, } \\
\text { job, morbidity, etc.) } \\
\text { included in analysis. } \\
\text { Job categories reported } \\
\text { and stratified into } \\
\text { hourly, salaried, and } \\
\text { executive. } \\
\text { Limitations: Sample } \\
\text { was predominately } \\
\text { young, hourly workers } \\
\text { with high levels of } \\
\text { occupational physical } \\
\text { activity. } \\
\text { Self-report CHD in } \\
\text { younger workers may } \\
\text { be under-reported. }\end{array}$ \\
\hline $\begin{array}{l}\text { Munir, et } \\
\text { al.* [39] }\end{array}$ & $\begin{array}{l}\text { To examine psychoso- } \\
\text { cial factors associated } \\
\text { with psychological and } \\
\text { health-related distress } \\
\text { among employees with } \\
\text { different chronic ill- } \\
\text { nesses. }\end{array}$ & $\begin{array}{l}\text { Cross-sectional study of } \\
4 \text { organizations across } 3 \\
\text { work sectors: local } \\
\text { government, transport } \\
\text { and manufacturing. }\end{array}$ & $\begin{array}{l}\text { Total Sample } \\
\mathrm{N}=1029 \\
47.9 \% \text { male } \\
\text { Mean age } 45.27 \\
9 \% \text { with heart disease } \\
72 \% \text { male } \\
\text { Mean age } 51.4 \text { yrs }\end{array}$ & $\begin{array}{l}\text { Workers with CHD were } \\
\text { significantly older; and re- } \\
\text { ported fewer work limita- } \\
\text { tions and fewer spells of } \\
\text { presenteeism } \\
\text { CHD predicted (poor) } \\
\text { psychological well-being } \\
\text { \& health distress } \\
\text { - } \quad \text { Psychological well-being } \\
\text { was associated with pre- } \\
\text { senteeism } \\
\text { Health-related distress was } \\
\text { associated with disclosure } \\
\text { of illness to employer }\end{array}$ & $\begin{array}{l}\text { Strengths: Covariates in } \\
\text { analysis included length } \\
\text { of employment, occupa- } \\
\text { tional group. } \\
\text { Included work-related } \\
\text { factors like workplace } \\
\text { support in analyses and } \\
\text { individual-level factors } \\
\text { (e.g., distress) } \\
\text { Limitations: Low re- } \\
\text { sponse rate (26\%) } \\
\text { CHD diagnoses were } \\
\text { self-reported with pri- } \\
\text { mary condition affecting } \\
\text { work, and symptoms } \\
\text { (e.g. anxiety, depres- } \\
\text { sion) categorized sepa- } \\
\text { rately from CHD }\end{array}$ \\
\hline
\end{tabular}


Table 1. Contd.....

\begin{tabular}{|c|c|c|c|c|c|}
\hline Study & $\begin{array}{l}\text { Relevant study Pur- } \\
\text { pose Study Design }\end{array}$ & Design & $\begin{array}{l}\text { Total Sample\% } \\
\text { CHD diagnosis }\end{array}$ & Related Key Findings & $\begin{array}{l}\text { Strengths and Limita- } \\
\text { tions }\end{array}$ \\
\hline $\begin{array}{l}\text { Munir, et } \\
\text { al.* [35] }\end{array}$ & $\begin{array}{l}\text { To measure work limi- } \\
\text { tations and work ad- } \\
\text { justments among } \\
\text { chronically ill employ- } \\
\text { ees with regard to } 3 \text { job } \\
\text { characteristics: physical } \\
\text { work demands, cogni- } \\
\text { tive work demands and } \\
\text { social work demands }\end{array}$ & $\begin{array}{l}\text { Cross-sectional study of } \\
\text { single organization (UK } \\
\text { University) }\end{array}$ & $\begin{array}{l}\text { Total Sample } \\
\mathrm{N}=610 \\
\text { Women } 64.7 \% \\
\text { Mean age } 42.4 \\
44.6 \% \text { with heart } \\
\text { disease }\end{array}$ & $\begin{array}{l}\text { - } 39.7 \% \text { reported work limi- } \\
\text { tations } \\
\text { - } \quad \begin{array}{l}\text { CHD was not a significant } \\
\text { predictor of work limita- } \\
\text { tions or work adjustments }\end{array} \\
\text { - } \quad \begin{array}{l}\text { Number of chronic condi- } \\
\text { tions reported was associ- } \\
\text { ated with physical and } \\
\text { cognitive work limitations. }\end{array} \\
\text { - General symptoms (e.g., } \\
\text { fatigue) resulted in most } \\
\text { limitations. } \\
\text { Depression had largest } \\
\text { impact on work limitations } \\
\text { (physical, cognitive and } \\
\text { social) }\end{array}$ & $\begin{array}{l}\text { Strengths: Subgroup (by } \\
\text { condition) analysis } \\
\text { reported. } \\
\text { Employment/job data } \\
\text { reported including } \\
\text { length of employment } \\
\text { and } \\
\text { organizational groups } \\
\text { (e.g., academic, clerical, } \\
\text { research, technical, etc.) } \\
\text { Instrument psychomet- } \\
\text { rics reported. } \\
\text { Limitations: CHD diag- } \\
\text { noses were self-reported } \\
\text { with primary condition } \\
\text { affecting work used in } \\
\text { analysis of predictors. } \\
\text { Symptoms (e.g. depres- } \\
\text { sion, fatigue) that co- } \\
\text { occur with CHD may } \\
\text { underestimate work } \\
\text { limitations. }\end{array}$ \\
\hline
\end{tabular}


Table 1. Contd.....

\begin{tabular}{|c|c|c|c|c|c|}
\hline $\begin{array}{l}\text { Goetzel, } \\
\text { et al. [42] }\end{array}$ & $\begin{array}{l}\text { To compare the differ- } \\
\text { ent estimates of absence } \\
\text { and presenteeism costs } \\
\text { imposed by certain } \\
\text { disease conditions. }\end{array}$ & $\begin{array}{l}\text { Cross-sectional study; } \\
\text { Secondary analysis of } \\
\text { integrated health and } \\
\text { productivity manage- } \\
\text { ment administrative } \\
\text { claims database com- } \\
\text { bined with } 5 \text { published } \\
\text { productivity studies. }\end{array}$ & $\begin{array}{l}\text { Total sample: } \\
\mathrm{N}=\text { not provided. } \\
\% \text { with heart disease } \\
\text { ranged by database: } \\
2-16.9 \%\end{array}$ & 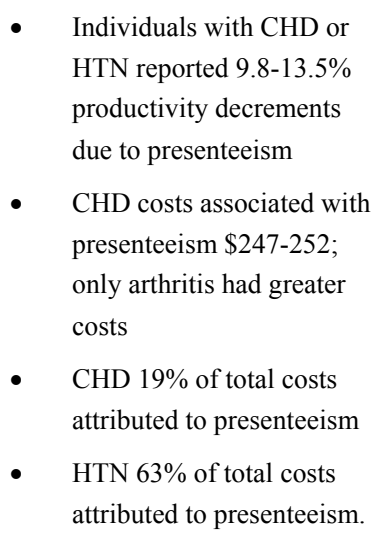 & $\begin{array}{l}\text { Strengths: Well- } \\
\text { established HPM data- } \\
\text { base with tested compu- } \\
\text { tations. } \\
\text { CHD diagnosis derived } \\
\text { as a combination of } \\
\text { claims and self-report } \\
\text { conditions } \\
\text { Limitations: Presentee- } \\
\text { ism measurement varied } \\
\text { and data not available } \\
\text { on all data sets. }\end{array}$ \\
\hline $\begin{array}{l}\text { Kivi- } \\
\text { maki, et } \\
\text { al.* }{ }^{[25]}\end{array}$ & $\begin{array}{l}\text { To examine the associa- } \\
\text { tion between sickness } \\
\text { presenteeism and inci- } \\
\text { dence of serious coro- } \\
\text { nary event }\end{array}$ & $\begin{array}{l}\text { Prospective cohort } \\
\text { study: (Whitehall II } \\
\text { Study) of British Civil } \\
\text { Servants (all male) }\end{array}$ & $\begin{array}{l}\text { Total Sample: } \\
\mathrm{N}=5071 \\
\text { Age (baseline) } 43.9 \\
3 \% \text { with heart disease }\end{array}$ & $\begin{array}{l}17 \% \text { of unhealthy employ- } \\
\text { ees took no absences in the } \\
3 \text { year period under study } \\
\text { (calculated as presentee- } \\
\text { ism) } \\
\text { Incidence of serious coro- } \\
\text { nary events was twice as } \\
\text { high in those with presen- } \\
\text { teeism compared to those } \\
\text { "unhealthy" who had ab- } \\
\text { sent periods reflecting ad- } \\
\text { verse effects of working } \\
\text { while ill. }\end{array}$ & $\begin{array}{l}\text { Strengths: Prospective } \\
\text { study and analysis of } \\
\text { well-described White- } \\
\text { hall Study II leveraging } \\
\text { large data set. } \\
\text { CHD diagnosis was } \\
\text { self-report with confir- } \\
\text { mation by clinical re- } \\
\text { cords } \\
\text { Limitations: Male } \\
\text { (100\%) sample with few } \\
\text { serious coronary events } \\
\text { so larger study is } \\
\text { needed. } \\
\text { Presenteeism calcula- } \\
\text { tion may be underesti- } \\
\text { mation. }\end{array}$ \\
\hline
\end{tabular}


Table 1. Contd.....

\begin{tabular}{|c|c|c|c|c|c|}
\hline $\begin{array}{l}\text { Loeppke, } \\
\text { et al. }[32]\end{array}$ & $\begin{array}{l}\text { To assess the magnitude } \\
\text { of health-related lost } \\
\text { productivity relative to } \\
\text { medical and pharmacy } \\
\text { costs for } 4 \text { employers. }\end{array}$ & $\begin{array}{l}\text { Cross-sectional study } \\
\text { across } 4 \text { companies } \\
\text { described as } 2 \\
\text { Industrial \& manufac- } \\
\text { turer, and } 2 \\
\text { computer \& } \\
\text { telecommunications }\end{array}$ & $\begin{array}{l}\text { Total Sample: } \\
\mathrm{N}=15,380 \\
\text { CHD specific sample } \\
\text { ( } \mathrm{n} \text { not provided) } \\
\text { listed as one of the } \\
\text { top } 10 \text { conditions } \\
\text { reported. }\end{array}$ & $\begin{array}{l}\text { - } \quad \text { HTN and high cholesterol } \\
\text { in top } 10 \text { drivers of lost } \\
\text { productivity (includes pre- } \\
\text { senteeism) } \\
\text { CHD is top driver of } \\
\text { health-related costs but not } \\
\text { significant in productivity } \\
\text { - Fatigue and depression } \\
\text { related productivity costs } \\
\text { are } 4 \mathrm{x} \text { that of medi- } \\
\text { cal/pharmacy costs. }\end{array}$ & $\begin{array}{l}\text { Strengths: Component } \\
\text { of a large Health and } \\
\text { Productivity Business } \\
\text { Strategy study. } \\
\text { CHD diagnosis reported } \\
\text { as self-report, medical } \\
\text { claims and pharmacy } \\
\text { data Limitations: Sam- } \\
\text { ple demographics not } \\
\text { provided; sub-group } \\
\text { analysis not reported. } \\
\text { Presenteeism not sepa- } \\
\text { rated from absenteeism } \\
\text { in final analysis of pro- } \\
\text { ductivity. }\end{array}$ \\
\hline $\begin{array}{l}\text { Lerner, } \\
\text { et al. [37] }\end{array}$ & $\begin{array}{l}\text { To estimate the total } \\
\text { prevalence of work } \\
\text { limitations among work- } \\
\text { ing people along with } \\
\text { health-specific condi- } \\
\text { tions. }\end{array}$ & $\begin{array}{l}\text { Cross-sectional study } \\
\text { of respondents to the } \\
\text { National Survey of } \\
\text { Functional Health Status } \\
\text { with work limitation } \\
\text { survey responses. Oc- } \\
\text { cupational groups cate- } \\
\text { gorized into manual } \\
\text { and "other" }\end{array}$ & $\begin{array}{l}\text { Total Sample } \\
\mathrm{N}=940 \\
\text { Female } 46 \% \\
\text { White } 83 \% \\
\text { Age } 40.7 \text { years } \\
21 \% \text { with heart dis- } \\
\text { ease }\end{array}$ & $\begin{array}{l}\text { - } 26 \% \text { with CHD reported } \\
\text { physical work limitations, } \\
27 \% \text { psychosocial limita- } \\
\text { tions; but NS } \\
\text { - } \begin{array}{l}\text { Depression increased odds } \\
\text { of limitations ( } 4 \mathrm{x})\end{array} \\
\text { Number of chronic condi- } \\
\text { tions associated with } \\
\text { physical and psychosocial } \\
\text { work limitations. }\end{array}$ & $\begin{array}{l}\text { Strengths: Psychomet- } \\
\text { rics of WLQ reported ( } \alpha \\
=.75) \\
\text { Job-related factors in- } \\
\text { cluding hours worked } \\
\text { and job type included in } \\
\text { analysis. } \\
\text { Limitations: CHD diag- } \\
\text { nosis from self-report } \\
\text { using checklist "similar } \\
\text { to" medical outcomes } \\
\text { survey; validation not } \\
\text { reported }\end{array}$ \\
\hline
\end{tabular}


Table 1. Contd.....

\begin{tabular}{|c|c|c|c|c|c|}
\hline Study & $\begin{array}{l}\text { Relevant study Pur- } \\
\text { pose Study Design }\end{array}$ & Design & $\begin{array}{l}\text { Total Sample\% } \\
\text { CHD diagnosis }\end{array}$ & Related Key Findings & $\begin{array}{l}\text { Strengths and Limita- } \\
\text { tions }\end{array}$ \\
\hline $\begin{array}{l}\text { Burton et } \\
\text { al. }[28]\end{array}$ & $\begin{array}{l}\text { To investigate the } \\
\text { prevalence in metabolic } \\
\text { syndrome in an em- } \\
\text { ployed population and } \\
\text { its association with } \\
\text { work limitations (pre- } \\
\text { senteeism) }\end{array}$ & $\begin{array}{l}\text { Cross-sectional study of } \\
\text { single, large multi-site } \\
\text { financial services corpo- } \\
\text { ration }\end{array}$ & $\begin{array}{l}\text { Total Sample } \\
\text { N=5512 } \\
\text { White } 58 \% \\
\text { Female } 61 \% \\
\text { Mean age } 41 \\
\\
22.6 \% \text { with meta- } \\
\text { bolic syndrome } \\
60 \% \text { female } \\
\text { (41\% with abnormal } \\
\text { cholesterol; } 58 \% \\
\text { female } \\
38 \% \text { with high blood } \\
\text { pressure; } 55 \% \text { fe- } \\
\text { male) }\end{array}$ & $\begin{array}{l}\text { - } 36-37 \% \text { with heart disease } \\
\text { reported work limitations } \\
\text { No significant association } \\
\text { between metabolic risk } \\
\text { factors (e.g., high blood } \\
\text { pressure, high cholesterol) } \\
\text { and presenteeism }\end{array}$ & $\begin{array}{l}\text { Strengths: Examined } \\
\text { cardiometabolic syn- } \\
\text { drome derived from } \\
\text { biometric screening and } \\
\text { HRA data. } \\
\text { Limitations: Presentee- } \\
\text { ism instrument ( } 8 \text { item } \\
\text { version of WLQ) psy- } \\
\text { chometrics not reported. } \\
\text { Recruitment from vol- } \\
\text { untary on-site HRA } \\
\text { screening so potential } \\
\text { bias of self-selection. } \\
\text { Potential lack of preci- } \\
\text { sion of worksite screen- } \\
\text { ing (not fasting/one- } \\
\text { time blood pressure } \\
\text { reading that were used } \\
\text { to define high blood } \\
\text { pressure and abnormal } \\
\text { cholesterol). }\end{array}$ \\
\hline
\end{tabular}

*=International Studies

Keys: AF - Atrial Fibrillation; CA - Cardiac Arrhythmia; CHD- coronary heart disease; HDL - high density lipids;; HRA- health risk appraisal; HTN- hypertension; NS- not significant; WLQ - work limitations questionnaire; WPSI- Work Productivity Short Index.

\section{RESULTS}

This review evaluated 12 studies that included 2 cohort studies and 10 cross-sectional studies. Only 2 studies specifically targeted CHD [25,26]; 6 included other diagnoses but provided results related to $\mathrm{CHD}$, and 3 used health risk data including biometric data (cholesterol and blood pressure) [27-29] to define "heart disease". The literature was fairly representative of varied workplace sectors that included government, healthcare and social assistance, public safety, services, transportation and manufacturing [30]. Within those sectors, common job categories reported were administrative, clerical, technical/skilled or semi-skilled. There were no studies that reported workers in mining or agricultural. Three studies reported findings from single employers [28, 29, 31].

There were 3 key findings of this literature review: 1) definitions and measurement of presenteeism and CHD diagnosis were inconsistent, 2) the primary focus was on quantifying the economic impact of presenteeism, and 3) joblevel and individual-level factors that potentially influence presenteeism were not addressed.

Interestingly, in this focused literature, presenteeism was defined in several ways. Most provided a definition of presenteeism consistent with Turpin et al. [9] as reduced productivity at work due to a health problem. Others defined presenteeism quantitatively as "on-the-job" time lost (e.g., total hours) [32] or commonly interchanged "work limitations" with presenteeism. The lack of conceptual clarity regarding presenteeism was further evident as some researchers refer to increased presenteeism as "over performing" and diminished presenteeism as "underperforming". An alternative taxonomy of absolute presenteeism and relative presenteeism was presented that considers one's performance within the context of others' [27].

Presenteeism was measured using a variety of standardized instruments including the Stanford Presenteeism Survey (SPS), Work Limitations Questionnaire (WLQ), World Health Organization Health and Work Performance Questionnaire (HPQ), Work Productivity Index (WPI) and its short inventory version (WPSI) (Table 2). Despite the availability of the above psychometrically sound instruments [33] and even a cardiac specific tool- the Angina-Related Limitations at Work Questionnaire [34]; none used disease-specific instruments and several studies described measuring presenteeism using study-specific measures. [25, 26, 28, 35] Only Munir [35,36] and Lerner [37] reported study specific instrument psychometrics. This is a notable limitation in this area of research. One study [35] that investigated work limitations and work adjustment among chronically ill employees $(n=610)$ reported low Cronbach's alpha in their use of a physical work limitations scale $(\alpha=.51)$. Results showed that physical work limitations increased as the number of chronic illnesses reported (including CHD) increased. Interestingly, cognitive work limitations also increased but reliability was adequate $(\alpha=.76)$. [35] Unfortunately, the authors do not provide any substantial information about their instrument. The low Cronbach's alpha may indicate the scale had too few items or lack of interrelatedness among the items to be reliable [38]. Or, it may be that the physical work limitations scale had not been sufficiently tested in the study's population of predominately sedentary workers. 
Table 2. Presenteeism Measurement

\begin{tabular}{|c|c|c|c|c|c|}
\hline Study & $\begin{array}{l}\text { Stanford Presentee- } \\
\text { ism Survey (SPS) }\end{array}$ & $\begin{array}{c}\text { Work Limitations } \\
\text { Questionnaire (WLQ) }\end{array}$ & $\begin{array}{l}\text { WHO Health and } \\
\text { Work Performance } \\
\text { Questionnaire (HPQ) }\end{array}$ & $\begin{array}{c}\text { Work Productivity Index } \\
\text { (WPI) or short inventory } \\
\text { version (WPSI) }\end{array}$ & Other \\
\hline Rohrbacker, et al. [26] & & & & & $\mathrm{X}$ \\
\hline Fonseca, et al. [31] & & & $\mathrm{X}$ & & \\
\hline Munir, et al. [39] & & $\mathrm{X}$ & & & $\mathrm{X}$ \\
\hline Munir, et al. [35] & & & & & $\mathrm{X}$ \\
\hline Collins, et al. [29[ & $\mathrm{X}$ & $\mathrm{X}$ & & & \\
\hline Terry \& Xi [27] & & & $\mathrm{X}$ & & \\
\hline Goetzel, et al. [42] & & & $\mathrm{X}$ & $\mathrm{X} / \mathrm{X}$ & \\
\hline Kivimaki, et al. [25] & & & & & $\mathrm{X}$ \\
\hline Lamb et al. [40] & & & & $\mathrm{X}$ & \\
\hline Loeppke, et al. [32] & & & $\mathrm{X}$ & & \\
\hline Lerner, et al. [37] & & $\mathrm{X}$ & & & \\
\hline Burton et al. [28] & & & & & $\mathrm{X}$ \\
\hline
\end{tabular}

Alternatively, Rohrbacker et al. [26] used an objective measurement of presenteeism, defined as decreased productivity, to describe the burden of atrial fibrillation and other heart arrhythmias in an employed population. In a two cohort design, productivity was objectively measured in a subset of employees by electronic measurement of units of work performed per day and hours worked per day. These data were collected for each employee on a daily basis for a year following the index date of diagnosis. Annual productivity output levels were significantly lower $(p=.0067)$ in the arrhythmia cohort groups and hourly productively differences trended towards significance level $(\mathrm{p}=.056)$, when other covariates were controlled. These objectively-measured data provide compelling evidence that symptoms commonly associated with heart arrhythmias such as fatigue may contribute to lower productivity, that is, presenteeism.

Similarly, methods used to assess CHD or identify persons as having CHD were varied. Medical claims, pharmacy data and/or disability data were often used to identify workers' with a chronic illness for study, while some studies relied on self-report or health risk appraisal data. For example, to determine the prevalence and estimated cost, including presenteeism of chronic illness for a specific employer workgroup, Collins, et al. [29] used ICD-9 codes from medical and pharmacy data along with self-reported health conditions to categorize individuals into a primary "chronic illness" group. Among the 7797 individuals responding to that study, $7.1 \%$ reported a primary health condition of CHD; while $12 \%$ reported having CHD regardless of whether it was "identified" as the primary condition. Although results did not rank CHD as a top contributor to presenteeism; the results reported a $19.9 \%$ decrement in work performance, i.e., presenteeism among those with CHD. Further, as the number of conditions increased that included CHD, the degree of limitations also increased. Conversely, Burton, et al. [28] used self-reported HRA data and biometric screening results to examine the prevalence and impact of metabolic syndrome including hypertension and high cholesterol in a large financial services employer group $(n=5512)$. They found no association of metabolic syndrome or cardiometabolic risk with presenteeism, which was measured by a short version of the WLQ. In addition to a lack of psychometrics for the measurements, limitations of that study include non-fasting biometric screening results, criteria for high blood pressure that did not consider pre-hypertension and self-reported health risks that may be subjectively biased. Therefore, cardiometablic risk in that study may be underestimated and presenteeism may be underreported in the employer-sponsored study.

Only two studies specifically focused on CHD diagnoses. $[25,26]$ Other studies categorized CHD through self-report $[31,35,37,39,40]$, biometric screening results $[27,28]$ or claims data $[29,32,41]$ and ranked importance of CHD compared to other conditions. Symptoms commonly associated with CHD (e.g., fatigue, depression, stress) were frequently clustered separately into either a mental health condition or general category. These symptoms were most often reported as significant correlates of presenteesim. Since few studies considered the overlapping nature of many symptoms and conditions, the relationship of CHD and presenteeism may be underestimated.

Clearly the focus of the extant literature is on quantifying the economic impact of presenteeism among worker populations or single employer groups. Primary aims focused on the impact of presenteeism as an economic outcome or assigned a "cost" to a similar concept (e.g., work limitation, loss productivity). For example, Loeppke et al., [32] discussed presenteeism as an important component of a company's business strategy to address health and productivity costs. Using the HPQ to assess self-reported presenteeism for health conditions across four companies, they matched 
medical and pharmacy claims to the self-reported health conditions to identify top drivers of health and productivity costs that included presenteeism. Coronary heart disease (CHD) and heart failure along with other cardiovascular conditions (hypertension and high cholesterol) were among the top 10 drivers of medical and pharmacy costs with estimated costs greater than $\$ 120,000 / 1000$ employees. However, only hypertension and high cholesterol were noted as significant productivity costs $(\$ 50,000$ to $100,000 / 1000 \mathrm{em}-$ ployees). Notably, depression, fatigue, and sleeping problems, which are common comorbid conditions among individuals with CHD were ranked second, third and fifth respectively. This highlights the potential underestimation of CHD-related presenteeism costs. Loeppke and colleagues [32] argued that examining the integrated costs including lost productivity is necessary in order to understand the full business impact. Yet, despite a very large integrated data base, researchers did not report subgroup analysis costs by job category or demographics which would have been very useful to advancing the understanding of how presenteesim might vary in diverse work groups.

In a similar analysis, Collins et al., [29] reported that CHD related conditions were estimated to "cost" about $\$ 5000$ per individual in work impairment. Certain jobs (skilled, unskilled and service workers) predicted greater work impairment than professional groups. Interestingly, in this study age also predicted presenteeism. That is, older workers reported less work impairment than younger $(<$ age 25 ) due to a chronic health condition. Findings that older workers experience less presenteeism [29] seem counterintuitive. However, large studies that integrated multiple data sources did not analyze costs by health condition leaving many unanswered questions.

Studies that examined the economic impact of chronic health conditions highlighted the prevalence of CHD in America's workforce and its significance as a driver of business health and productivity costs. For example, a secondary analysis of integrated health and productivity management administrative claims data base with 5 published productivity studies reported CHD prevalence rates of $2-16.9 \%$ with associated costs attributed to presenteeism at $\$ 247-252$ per employee [42]. In this analysis, $19 \%$ of the total health and productivity costs of CHD were attributed to presenteeism. Of particular importance was the report that $63 \%$ of total costs related to hypertension were productivity or presenteeism costs, since hypertension is a significant risk factor for CHD.

A third and related key finding was that few studies considered how job-level factors or individual-level factors influence presenteeism. Studies described job-level factors such as job stress [28], workplace support [39], work adjustments [35], job satisfaction [27], and shift work [31] in order to describe the sample but few analyzed the relationships between these factors and presenteeism. Munir et al. [39] examined the association of workplace support, work limitations and "spells of presenteeism" among workers categorized into six health conditions $(\mathrm{n}=1029)$ including 96 workers with CHD (mean age 51.4 years). There were no significant associations between workplace support and presenteeism in any of the chronic condition groups. Compared with workers who reported depression and anxiety, the cohort with CHD reported better psychological well-being, less health distress and less presenteeism but higher levels of illness disclosure (NS). In a second related study, Munir and colleagues [35] examined predictors of work adjustments and found disclosure of condition to employer was significant. This work suggests that the work environment when supportive can buffer psychological distress in workers with chronic illness. Workers with CHD may be more likely to disclose their illness whereas other conditions like depression may carry a stigma.

Job satisfaction was the most frequently measured joblevel factor in this literature and a significant predictor of presenteeism. In a study of 631 airline and healthcare system employees [27], job satisfaction and self-reported job performance were both significantly associated with presenteeism. That is, high job satisfaction and heightened job performance were associated with highly productive employees but analyses by age, job category and chronic illness were not explored. The authors cautioned that in their sample, the healthcare worker cohort may have underreported chronic illness and productivity, which they attributed to an "inflated self-image" [27]. This acknowledged limitation in their work highlights the overarching weakness in this body of literature. That is, much of the data are self-reported without corroboration; and additional subgroup analysis that might investigate potential mediation or moderation relationships (e.g., age, health condition, etc.) is lacking.

Although sociodemographic results were typically reported in describing the samples, other individual-level factors like work attitudes and personality were not measured. Subjective perceived health status was, however, reported as significantly associated with presenteeism in several studies. [27, 28] For example, Terry et al. [27] reported that higher perceived health status was correlated to absolute presenteeism (high performance). Interestingly, among individuals with high blood pressure, $68.7 \%$ reported high performance compared to $55 \%$ of other groups $(\mathrm{p}=.01)$. This finding supports the hypothesized relationship of subjective ratings of health and presenteeism. Perceived health status may reflect an individual's tendency to adopt a sick role and influence whether someone will attend work even when feeling ill [13].

\section{DISCUSSION}

The results of this literature review reveal several gaps in the current literature about presenteeism and older workers with CHD. Importantly, the literature has not adequately investigated the older worker population which according to the US Bureau of Labor Statistics is age 50 years or older. This is an important gap in the literature because by 2015 , the number of workers age 55 years and older will reach 31.2 million; a $72 \%$ increase from 2000 [1]. As part of the aging process, older adults are also likely to experience multiple comorbid conditions. Therefore, the finding that the number of conditions is predictive of presenteeism [29, 35] highlights the need for future research to examine the work patterns of the older worker cohort.

Understanding presenteeism in older workers with CHD will also entail examining individual level factors like work 
attitudes, personality and sick role. According to Society of Health and Human Resources [19] older workers have greater organizational commitment and loyalty; attributes that employers value. However, for older workers with CHD, these characteristics may negatively impact health. For example, working while ill may produce a cumulative psychological burden consistent with the pathophysiology, i.e., allostatic load hypothesis of CHD [43]. In addition, acute stressors may act on preexisting vascular disease precipitating an acute event [44].

Further, none of the studies in this review used a theoretical framework or conceptual model. In fact, presenteeism research has been called "markedly atheoretical" [13]. John's dynamic model of presenteeism and absenteeism illustrates the multi-contextual process by which productivity is interrupted by a health event [13]. According to this model, the degree of presenteeism and/or absenteeism is influenced by organizational and job-level factors including job demands, job security, workplace support and individual attributes like attitudes. Cumulative consequences of presenteeism or absenteeism are defined as productivity, attendance, and tenure (i.e., length of employment). Another proposition is that presenteeism and absenteeism in turn influence the health event. This is particularly important in older workers with CHD who may experience deteriorating health if symptoms are ignored or exposure to stress is unalleviated. An alternative conceptual model that could be adapted for use to support research in the older worker population is the holistic model of stress [45], since presenteeism is shown as an outcome of that model. Research study designs guided by a conceptual framework, notably absent in this literature review, may help delineate and explain hypothesized relationships among variables and outcomes; and ensure all of the appropriate factors are included.

Finally, in most cases, studies reviewed handled CHD as a discrete diagnosis and differentiated symptoms of fatigue, depression and sleepiness. Therefore, results may underestimate how clusters of symptoms commonly associated with CHD influence presenteeism. This is an important gap in the current literature because there is clear evidence that some symptoms like depression, found in $10-20 \%$ of patients with CHD [46], may be particularly stigmatizing in employed populations. According to Munir [35], disclosure is necessary for work adjustments that can facilitate work productivity and ameliorate presenteeism. Furthermore, CHD symptoms may be episodic, or occur in clusters. Examining how $\mathrm{CHD}$ and related symptoms influence presenteeism or work limitations over a period of time may help address the gap in the literature.

\section{LIMITATIONS}

It is important to note several limitations of this review. First, not all studies reported sample demographics or job categories for subsets of data. Therefore, differences in presenteeism among workers with CHD by demographics including age, gender and marital status were not able to be determined. Additional exploration of these relationships among workers in physically demanding jobs is also indicated. Similarly, few studies reported race and those that did were predominately Caucasian. Since ethnic minority popu- lations with CHD experience poorer outcomes than Caucasians, it would be interesting to see if presenteeism issues differ in ethnic minority workers with CHD.

\section{CONCLUSIONS}

Changing workforce demographics that include a growing proportion of older workers and an increasing trend towards postponed retirement require that researchers expand their methods to investigate presenteeism among older workers with CHD. For example, longitudinal research that examines the multi-level dimensions of the work environment including organizational policies, job-level factors and individual-level variables are indicated. In addition, in order to understand presenteeism in older workers with CHD, researchers may need to move outside the focused single workforce or similar employer groups that limit generalizability of findings. In addition, use of the occupational and psychosocial epidemiology framework [47] or a similar conceptual model $[13,45]$ has potential to guide research that examines the multi-dimensional factors including psychosocial work exposures that likely contribute to presenteeism among older workers with CHD.

\section{CONFLICT OF INTEREST}

The authors confirm that this article content has no conflicts of interest.

\section{ACKNOWLEDGEMENTS}

Center for Disease Control and Prevention (CDC) and National Institute for Occupational Safety and Health (NIOSH) K01 Career Development Award in Occupational Safety and Health Research: 5K01OH009785-02

\section{REFERENCES}

[1] Bureau of Labor Statistics. Spotlight on statistics: older workers. [document on the Internet]. U.S. Department of Labor [updated 2008 April 29; cited 2012 May 4]. Available from: http://www.bls.gov/spotlight/2008/older_workers/

[2] Pfizer US. Pharmaceuticals. The health status of the United States workforce. [document on the Internet]. Pfizer Incorporated [updated 2007 January; cited 2012 May 4]. Available from: http://www.pfizer.com/files/products/The_Health_Status_of_the United_States_Workforce_2007.pdf

[3] NCHS. National Health \& Nutrition Examination Survey (NHANES III), 1988-1994. [document on the Internet] U.S. Department of Health and Human Services Center for Disease Control and Prevention; [updated 2012 April 30; cited 2012 May 4]. Available from: http://www.cdc.gov/nchs/nhanes/nh3data.htm

[4] McGovern P, Jacobs D, Shahar E, et al. Trends in acute coronary heart disease mortality, morbidity, and medical care from 1985 through 1997: the Minnesota heart survey. Circulation 2001; 104 : 19-24.

[5] Hemingway H, Vahtera J, Virtanen M, Pentti J, Kivimaki M. Outcome of stable angina in a working population: the burden of sickness absence. Eur J Cardiovasc Prev Rehabil 2007; 14: 373-9.

[6] Burnier M. Medication adherence and persistence as the cornerstone of effective antihypertensive therapy. Am J Hypertens 2006; 19:1190-6.

[7] Lepine J-P, Briley M. The increasing burden of depression. Neuropsychiatr Dis Treat 2011; 7: 3-7.

[8] Kessler R, Berglund P, Coulouvrat C, et al. Insomnia and the performance of us workers: results from the America insomnia study. Sleep 2011; 34:1161-71. 
[9] Turpin R, Ozminkowski R, Charda C, Collins J, Berger M, Billotti G. Reliability and validity of the Stanford presenteeism scale. J Occup Environ Med 2004; 46(4): 398-412.

[10] Schultz A, Edington D. Employee health and presenteeism: a systematic review. J Occup Rehabil 2007; 17: 547-79.

[11] Lack D. Presenteeism revisited: a comprehensive review. AAOHNJ 2011; 59: 77-89.

[12] Lovell V. No time to be sick: Why everyone suffers when workers don't have paid sick leave. Washington DC: Institute for Women's Policy Research 2004.

[13] Johns G. Presenteeism in the workplace: a review and research agenda. J Organ Behav 2010; 31: 519-42.

[14] Gilbreath B, Karimi L. Supervisor behavior and employee presenteeism. Int J Leadership Stud 2012; 7:114-31.

[15] Demerouti E, LeBlanc P, Bakker A, Schaufeli W, Hox J. Present but sick: a three-wave study on job demands, presenteeism and burnout. Career Dev Int 2009:14; 50-68.

[16] Gryner A Singleton V. Sickness absence as risk-taking behavior: a study of organizational and cultural factors in the public sector. Health, Risk Soc 2000; 2: 7-21.

[17] Aronsson G, Gustafsson K. Sickness, presenteeism: prevalence, attendance-pressure factors, and an outline of a model for research. J Occup Environ Med. 2005; 47: 958-966

[18] Johansson G, Lundberg I. Adjustment latitude and attendance requirements as determinants of sickness absence or attendance: empirical tests of the illness flexibility model. Soc Sci Med 2004; 58:1857-68.

[19] Gurchiek K. Sense of duty beckons sick employees to work. [document on the Internet] Society for Human Resource Management: HR News. [updated 2008 April 29; cited 2012 May 4] Available from: http://www.shrm.org/Publications/HRNews/Pages/Sense ofDutyBeckons.aspx2008

[20] Hemp P. Presenteeism: at work - but out of it. Harv Bus Rev 2004; 82: $49-58$

[21] $\mathrm{Ng} \mathrm{T}$, Feldman D. The relationships of age with job attitudes: a meta-analysis. Pers Psychol 2010; 63: 677-718.

[22] Fukuoka Y, Takeshima M, Ishii N, et al. Long working hours and delay in seeking care during acute coronary events in U.S. and Japanese samples. Circulation 2008; 118: S825.

[23] Moher D, Liberati A, Tetzlaff J, Altman D, The PRISMA Group. preferred reporting items for systematic reviews and meta-analyses: the prisma statement. Ann Intern Med 2009; 151: W65-94.

[24] Chapman L. Presenteeism and its role in worksite health promotion: practical information to make programs more effective. The Art of Health Promotion 2005:1-14.

[25] Kivimki M, Head J, Ferrie J, et al. Working while ill as a risk factor for serious coronary events: the whitehall II study. Am J Public Health 2005; 95: 98-102.

[26] Rohrbacker N, Kleinman N, White S, March J, Reynolds M. The burden of atrial fibrillation and other cardiac arrhythmias in an employed population: associated costs, absences, and objective productivity loss. J Occup Environ Med 2010; 52: 383-91.

[27] Terry P, Xi M. An examination of presenteeism measures: the association of three scoring methods with health, work life, and consumer activation. Popul Health Manag 2010; 13: 297-307.

[28] Burton W, CY C, Schultz A, Edington D. The prevalence of metabolic syndrome in an employed population and the impact on health and productivity. J Occup Environ Med 2008; 50: 1139-48.
[29] Collins J, Baase C, Sharda C, et al. The assessment of chronic health conditions on work performance, abence and total economic impact for employers. J Occup Environ Med 2005; 47: 547-57.

[30] NIOSH. NIOSH program portfolio. [document on the Internet] Centers for Disease Control. [updated 2011 June 10; cited 2012 May 4] Available from: http://www.cdc.gov/niosh/programs/

[31] Fonseca V, Nobre MRC, Pronk N, Santos L. The association between physical activity, productivity, and health care utilization among employees in brazil. J Occup Environ Med 2010; 52: 70612.

[32] Loeppke R, Taitel M, Richling D, et al. Health and productivity as a business strategy. J Occup Environ Med 2007; 49(12):1299-300.

[33] Brooks A, Hagen S, Sathyanarayanan S, Schultz A, Edington D. Presenteeism: critical issues. J Occup Environ Med 2010; 52: 105567.

[34] Lerner D, Amick III B, Malspeis S, Rogers D, Gomes J, Salem D. The angina-related limitations at work questionnaire. Qual Life Res 1998; 7: 22-32.

[35] Munir F, Jones D, Leka S, Griffiths A. Work limitations and employer adjustments for employees with chronic illness. Int J Rehabil Res 2005; 28:111-17.

[36] Munir F, Yarker J, Haslam C. Use of prescribed medication at work in employees with chronic illness. Occup Med 2007; 57: 4807.

[37] Lerner D, Amick III B, Malspeis S, Rogers W. A national survey of health-related work limitations among employed persons in the united states. Disabil Rehabil 2000; 22: 225-32.

[38] Tavakol M, Dennick R. Making sense of cronbach's alpha. Int J Med Edu 2011; 2: 53-5.

[39] Munir F, Yarker J, Haslam C, et al. Work factors related to psychological and health-related distress among employees with chronic illnesses. J Occup Rehabil 2007; 17: 259-77.

[40] Lamb C, Ratner P, Johnson C, et al. Economic impact of workplace productivity losses due to allergic rhinitis compared with select medical conditions in the united states from an employer perspective. Curr Med Res Opin 2006; 22: 1203-10.

[41] Goetzel R, Long S, Ozminkowski R, Hawkins K, Wang S, Lynch W. Health, absence, disability, and presenteeism cost estimates of certain physicl and mental health conditions affecting us employers. J Occup Environ Med 2004; 46: 398-412.

[42] Goetzel R, Long S, Ozminkowski R, Hawkins K, Wang S, Lynch W. Health, absence, disability, and presenteeism cost estimates of certain physical and mental health conditions affecting U.S. Employers. J Occup Environ Med 2004; 46: 398-412.

[43] Schnorpfeil P, Noll A, Schulze R, Ehlert U, Frey K, Fischer J. Allostatic load and work conditions. Soc Sci Med 2003; 57: 64756.

[44] Kivimki M, Head J, Ferrie J, et al. Working while ill as a risk factor for serious coronary events: the whitehall ii study. Am J Pub Health 2005; 95: 98-102.

[45] Nelson D, Simmons B. Health psychology and work stress: a more positive approach. In: Quick J, Tetrick L, Eds. Handbook of occupational health psychology. Washington DC: Am Psychol Assoc 2003. p. 102 .

[46] Lichtman J, Bigger J, Blumenthal J, et al. Depression and coronary heart disease. Circulation 2008; 118: 1768-75.

[47] Kasl S, Jones B. An epidemiological perspective in research design, measurement and surveillance strategies. In: Quick J, Tetrick L, Eds. Handbook of occupational health psychology. Washington DC: Am Psychol Assoc 2011; pp.375-95.

(C) Victoria Vaughan Dickson; Licensee Bentham Open.

This is an open access article licensed under the terms of the Creative Commons Attribution Non-Commercial License (http://creativecommons.org/licenses/ by-nc/3.0/) which permits unrestricted, non-commercial use, distribution and reproduction in any medium, provided the work is properly cited. 